important work on oxygen-want at high altitudes, finding that animals could not continue for long to live at altitudes above 20,000 $\mathrm{ft}$. This degeneration has been fully confirmed for man by the experiences reported by Everest climbers such as Mr. Shipton. Although 27,000 $\mathrm{ft}$. has been reached, the incapacity of the climbers is such that there is little hope of Everest being climbed without use of oxygen-breathing apparatus, and that use is beset with difficulties.

Campbell pointed out that one of the means of acclimatization to high altitudes was hypertrophy of the heart. His work on oxygen-want led to the contrivance of a simple but effective oxygen-breathing face mask. With the late Dr. Poulton he published a valuable book on "Oxygen and Carbon Dioxide Therapy", a standard work on the subject. Further researches showed him that oxygen-want is better resisted on a certain diet, such as one of carrots, and this inquiry led to possible means of improving the resistance of high flyers. He also found that the effects of oxygen poisoning at high pressures are warded off by a fall in body temperature; animals are more susceptible at high than at low external temperature.

With me he carried out an investigation of the washing out of nitrogen dissolved in the body by the breathing of oxygen, and the amount of nitrogen in the bone marrow of animals exposed to high air pressures-work of interest in regard to compressedair illness.

Another important line of inquiry carried out by Campbell was on the effect of inhalation of dust on the production of pulmonary cancer. He found that tar-containing dust from roads greatly increased the frequency of such cancer in mice; dust not containing tar did so also, but to much less extent.

Whatever researches Campbell carried out, of which a few have been mentioned, were executed with the greatest accuracy and thoroughness, so that his results stand unquestioned. He was so deaf that one had to communicate with him by writing, and this fact prevented all but a few from realizing his high worth and modest character. LEONARd HILL.

\section{Mr. E. C. Stuart Baker, C.I.E.}

BY the death of Mr. Stuart Baker on April 16 at the age of seventy-nine, ornithology, and especially Indian ornithology, has lost one of its most eminent exponents. He was born in 1864; after being educated at Trinity College, Stratford-on-Avon, he followed his father's career in entering the Indian Police Force in 1883. Nearly all his service was spent in Assam, then, even more so than now, a wild mountainous region peopled by primitive and savage tribes, which offered unbounded opportunities for sport and the observation of wild life, of which he took every advantage. He rose to be officiating inspector of police for the Province in 1910; in 1912 he was selected to reorganize the special police force of the Port of London Authority, a post which he held until he retired in 1925 .

On his return to England Stuart Baker settled at Upper Norwood and, taking an interest in local polities, he was elected a councillor of the Croydon Town Council, where he served two terms as mayor during 1937-38.

It was not until about the time of his return from India that Stuart Baker began to publish his numerous works on Indian ornithology. These include volumes on the Indian ducks, doves and game-birds, and finally he was asked to prepare a new edition of the birds for "The Fauna of British India" series, issued under the authority of the Secretary of State for India in Council. The first edition by E. W. Oates and W. T. Blanford was in four volumes. Stuart Baker expanded these into eight, published during 1922-30, and practically rewrote the whole. It has since become the standard work on the subject. As he felt he had not done justice, for want of space, to nesting and other habits, he prepared four more volumes, "The Nidification of Birds of the Indian Empire", which appeared during 1932-35.

Perhaps Stuart Baker's most valuable work was on the cuckoo problem. Always deeply interested in the study of birds' eggs, of which he amassed a very large collection, he paid special attention to the cuckoos, especially those of the many Indian and Asiatic species. The results of these observations and reflexions appeared in 1942 under the title of "Cuckoo Problems", in which he discussed such questions as adaptation of cuckoo's eggs to those of the fosterers, how far the 'survival of the fittest' has been concerned in the evolution and adaptation of the eggs, and such lesser questions as the method by which the cuckoo egg has been introduced into the nest of the fosterer and the ejection of fosterers' eggs from the nest by the young cuckoo. The value of this work was greatly enhanced because Baker had at his disposal much evidence from the many Indian species and did not confine himself to the European cuckoo, which had been the case with most previous writers.

Stuart Baker received the C.I.E. in 1932. He was a fellow of the Linnean and Zoological Societies and a member of the British Ornithologists' Union, of which he was honorary secretary and treasurer from 1913 until 1936.

He married in 1897 Ethel May Roffey, who survives him together with four daughters. W. L. SCLATER.

\section{Mr. J. W. Bullerwell}

JoHN WILLIAM BULLERwell began teaching (two years before he entered college) as an assistant master at the Orphan House School, Newcastle, where he had previously been a student. While an undergraduate at Armstrong College, he taught mathematics and mechanics in Newcastle School Board evening schools, and after graduating in 1896 he became science master at St. Cuthbert's Grammar School and part-time lecturer in mathematics at Armstrong College. In 1901 he became lecturer in mathematics at Hartley College, Southampton, a post which he held only for a short time, before returning to Newcastle as lecturer in physics in 1902, becoming senior lecturer in 1919 . He retired in 1938, but returned to duty again until 1942 .

Two or three generations of students will remember Bullnrwell for his novel and well-thought-out methods of presenting his subject. He was above all other things a teacher, whose every desire was to help and advise his students. He had no grudges against anyone, and he was always ready to rejoice in the promotions and successes of others. With his six feet four inches he commanded discipline with ease, but it was always a parental rather than a dictatorial discipline.

Bullerwell was appointed secretary of the University of Durham Schools Examination Board in 1932, and he carried out the duties with efficiency until 
illness forced him to retire in 1942. He acted as treasurer of the Armstrong (later King's) College Choral and Orchestral Society for forty years and in the same capacity for the University of Durham Philosophical Society. The Newcastle Bach Choir was one of his greatest interests, and he was associated with it from the time of its foundation. For many years also he was a member of the committee of the Newcastle upon Tyne Literary and Philosophical Society. He had some rэputation as a collector of North Country folk songs, and many people will have pleasant memories of his lectures on the subject.

Bullerwell died on March 17 at the age of seventy. George W. Todd.

\section{Prof. W. G. MacCallum}

Prof. William George MacCallum, the eminent American pathologist, who died on February 3 at the age of sixty-nine, was born at Dunnville, Ontario, on April 18, 1874, the son of a medical man. After qualifying at the University of Toronto in 1894 and at the Johns Hopkins University School of Medicine in 1897, he held the post of intern and later of resident pathologist at the Johns Hopkins Hospital. In 1899 he was appointed assistant in pathology at Johns Hopkins, where he afterwards became assistant professor and professor in pathological physiology and lecturer in forensic medicine. In 1909 he was appointed professor of pathology at the Columbia University College of Physicians and Surgeons, as well as pathologist at the German Hospital and Presbyterian Hospital. In 1917 he succeeded the well known pathologist Dr. William H. Welch as professor of pathology at Johns Hopkins, and held this appointment until the spring of 1943 .
In addition to a "Text-book of Pathology", of which the first edition appeared in 1916 and the seventh and last in 1940, MacCallum's chief publications were on the sexual conjugation of the parasites of avian malaria (1897), the pathology of pneumonia following influenza in the United States during the winter of 1917-18, calcium in tetany (1918), and with Ella H. Oppenheimer "Centrafugalization, a Method for the Study of Filtrable Viruses as applied to Vaccinia". He was also the author of a biography of the surgeon W. S. Halstead.

MacCallum was well known in Great Britain, where he was elected an honorary fellow of the Royal Society of Medicine in 1934. He was also honorary fellow of the Swedish Medical Society at Stockholm, a member of the U.S. National Academy of Sciences, and of the Harvey Society, of which he was president in 1914 . J. D. Rolleston.

We regret to announce the following deaths :

Dr. J. C. Dunlop, formerly registrar-general for Scotland, and an honorary fellow of the Faculty of Actuaries of Scotland, on April 10, aged seventyeight.

Sir Clement Hindley, K.C.I.E., member of the Advisory Council for Scientific and Industrial Research, and president in 1939 of the Institution of Civil Engineers, on May 3, aged sixty-nine.

Mr. C. B. Rickett, an authority on the birds of southern China, aged ninety-three.

Commander J. A. Slee, C.B.E., chairman in 1938 of the Wireless Section of the Institution of Electrical Engineers, aged sixty-five.

Prof. W. M. Thornton, O.B.E., emeritus professor of electrical engineering at King's College, Newcastle upon Tyne, on May 2, aged seventy-four.

\section{NEWS and VIEWS}

\section{Water Supply in Great Britain}

A White PAPER on water supplies ("A National Water Policy." H.M. Stationery Office, 6d.) points out that the problem facing Great Britain is one of organization and distribution, not of total resources, which are ample for all needs. Since water is a bulky commodity, its costs of distribution are relatively high and therefore local sources must be used so far as possible. To do this efficiently will require, not only changes in law and practice, with the coordination of the many varied authorities up and down the country, but also a fuller survey of resources than is at present available, and adequate protection against pollution and waste. There must also be a satisfactory supply for industrialists and farmers, who now are normally outside the obligations of public water-undertakings. Agricultural production must no longer be hampered by insufficiency of water and haphazard dependence on casual supplies. The proposals embodied in this report are based on three principles : first, adequate control of water supply services, including changes where they can be justified by greater efficiency or reduction in costs; secondly, responsibility for water supply to rest with democratic bodies ranging from Parliament to local authorities; and thirdly, sectional interests to be subordinate to the national interest, subject to Parliamentary approval.
In the light of these principles, the main proposals of the Government are as follow : the Minister of Health and the Secretary of State for Scotland would be given the statutory duty of promoting the provision of adequate water supply and the conservation of water resources, and their policy would be based on the collection of full information regarding sources and needs. The Central Advisory Water Committee of England and Wales should be reconstituted as a statutory body, and a similar committee set up for Scotland. Survey of the needs of large areas and the efficiency of supplies should be eontinued, close touch being maintained with town and country planning policies. Amalgamation of water undertakings may be necessary in order to secure efficiency and economy, and also the giving of bulk supplies by one water undertaking to another. Steps must be taken to prevent misuse, waste and pollution. Industry and agrieulture are to have the right to water supplies. Compulsory powers, under proper safeguards, should be granted to take water from streams. The Ministers responsible should be given powers to require information and statistics from all users of water and sinkers of wells. The White Paper also contains certain financial proposals; but its main importance is that it considers the problems of water supply on a national basis, and admits the need for rural supplies, even though urban 